\title{
PENGETAHUAN IBU TENTANG KEBIASAAN MINUM SUSU FORMULA MELALUI BOTOL DAN STATUS KARIES GIGI SUSU PADA ANAK USIA PRASEKOLAH
}

\author{
Emini $^{1}$, Jusuf Kristianto ${ }^{2}$, Ita Yulita ${ }^{3}$, Erwin $^{4}$, Nanda Mei Shara ${ }^{5}$ \\ 1,2,3,4,5 Jurusan Keperawatan Gigi, Politeknik Kesehatan Kemenkes Jakarta I, Indonesia
}

\begin{tabular}{ll}
\hline Info Artikel & Abstrak \\
\hline Genesis Naskah: & $\begin{array}{l}\text { Pemeliharaan dan status kesehatan gigi anak usia prasekoh masih bergantung kepada } \\
\text { perilaku orang tua, khususnya ibu sebagai figur terdekat, termaksud pengetahuan tentang }\end{array}$ \\
$\begin{array}{l}\text { Submitted : 20 Agustus 2020 } \\
\text { Revised : 19, 21 September }\end{array}$ & $\begin{array}{l}\text { kebasaan konsumsi susu formula melalui botol harus diterapkan dengan tepat agar } \\
\text { mencegah kasus karies gigi susu pada anak. Tujuan dari penelitian ini adalah untuk } \\
\text { mengetahui gambaran pengetahuan ibu tentang kebiasaan minum susu formula melalui }\end{array}$ \\
Accepted :5 Oktober 2020 & $\begin{array}{l}\text { botol dan status karies gigi susu pada anak usia prasekolah di PAUD Nurul Iman Radio } \\
\text { Dalam. Jenis Penelitian ini adalah deskriptif. Penelitian ini menggunakan 60 sampel }\end{array}$ \\
Kata Kunci: & yang terdiri atas anak beserta ibu yang diambil dengan teknik total sampling. Instrumen \\
Pengetahuan Ibu, karies & yang digunakan dalam penelitian ini adalah wawancara dan pemeriksaan status karies \\
gigi susu & gigi susu. Hasil penelitian diketahui pengetahuan ibu mayoritas pada kategori baik yaitu \\
& 19 orang (37\%), sedangkan status karies gigi susu anak mayoritas pada kategori sedang \\
& yaitu 10 orang (33,3\%). Kesimpulan hasil penelitian ini adalah umumnya pengetahuan \\
ibu tentang kebiasaan minum susu formula melalui botol pada kategori baik dan status & karies gigi susu anak pada kategori sedang.
\end{tabular}

THE MOTHER'S KNOWLEDGE ABOUT THE HABIT OF DRINKING FORMULA MILK THROUGH A BOTTLE AND STATUS OF PRIMARY DENTAL CARIES IN PRE-SCHOOL AGE

\section{Keywords:}

Mother's Knowledge, primary dental caries

\section{Abstract}

The maintenance and dental health status of preschool children still depends on the behavior of parents, especially mothers as the closest figure, meaning that knowledge about the habit of consuming formula milk through bottles must be applied appropriately in order to prevent cases of dental caries in children. The purpose of this study was to describe the knowledge of mothers about the habit of drinking formula milk through bottles and the caries status of milk teeth in preschool children at Nurul Iman Radio Dalam PAUD. This type of research is descriptive. This study used 60 samples consisting of children and mothers who were taken by total sampling technique. The instruments used in this study were interviews and check the caries status of milk teeth. The results showed that the majority of mothers' knowledge was in the good category, namely 19 people (37\%), while the majority of the children's milk teeth caries status was in the moderate category, namely 10 people (33.3\%). The conclusion of this study is that generally the knowledge of mothers about the habit of drinking formula milk through bottles is in the good category and the caries status of children's milk teeth is in the moderate category.

(C) Jurusan Keperawatan Gigi Poltekkes Kemenkes Jakarta I J1. Wijaya Kusuma No. 47-48 Cilandak Jakarta Selatan, Indonesia email: jdht@poltekkesjakarta1.ac.id

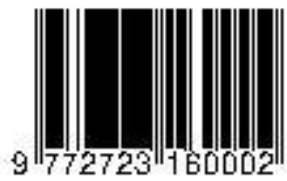


Korespondensi Penulis:

Erwin

Jl. Wijaya Kusuma No. 47-48 Cilandak Jakarta Selatan

Email : erwin7tgm@gmail.com

\section{Pendahuluan}

Menurut WHO sehat merupakan keadaan sejahtera secara fisik, mental, dan sosial yang merupakan suatu kesatuan, bukan hanya terbebas dari penyakit maupun cacat. Sejalan dengan definisi sehat menurut WHO, dalam Permenkes nomor 89 tahun 2015 dinyatakan kesehatan gigi dan mulut merupakan bagian integral dari kesehatan tubuh secara keseluruhan, sehingga pemeliharaan kesehatan gigi dan mulut penting dilakukan (Sandy, 2018).

Data Riskesdas (2018) menyebutkan bahwa 93\% anak usia dini, yakni dalam rentang usia 5-6 tahun, mengalami gigi berlubang. Ini berarti hanya $7 \%$ anak di Indonesia yang bebas dari masalah karies gigi. Permenkes 89 tahun 2015 menyatakan Pelayanan Kesehatan Gigi dan Mulut pada anak balita dan anak usia prasekolah dilakukan dalam rentang usia 12 (dua belas) sampai 72 (tujuh puluh dua) bulan. dilakukan dengan memberikan Komunikasi, Informasi dan Edukasi (KIE) kepada orang tua dan/atau anggota keluarga lain. Keterlibatan orang tua dan/atau anggota keluarga lain harus dilakukan secara aktif agar pembentukan perilaku sehat dan kemandirian anak balita dan anak usia prasekolah optimal dalam pemeliharaan dan peningkatan kesehatan gigi dan mulut.

Community Dental Oral Epidimiology menyebutkan bahwa anak usia Taman Kanak-Kanak (TK) di Indonesia memiliki risiko besar terkena karies. Pada anak usia Taman Kanak-kanak, perawatan gigi dan mulut masih bergantung kepada perilaku orang tua, khususnya ibu sebagai figur terdekat seorang anak. Pengetahuan dan perilaku ibu memiliki pengaruh dalam membimbing, memberikan penjelasan dan mengawasi anak dalam memelihara kesehatan gigi dan mulutnya secara baik dan benar yang berpengaruh terhadap risiko terjadinya karies pada anak tersebut (Jyoti, 2019)

Pengetahuan ibu yang kurang baik akan mempengaruhi pola asuh kepada anak sehingga dapat berdampak pada status kesehatan gigi anak. penelitian yang dilakukan oleh Solikin (dalam Rompis, 2016) di Karanganyar pada tahun 20013, menunjukan bahwa, pada ibu dengan pengetahuan kategori kurang baik mengakibatkan mayoritas anak mengalami karies gigi sebesar $97,6 \%$.

Dengan alasan bermacam-macam ibu memutuskan untuk mengganti ASI dengan susu formula. Suatu presentase menunjukkan bahwa Susu formula merupakan suatu produk makanan yang mengandung nilai gizi cukup tinggi, karena sebagian besar zat gizi esensia; seperti protein, kalsium, fosfor, vitamin A, dan vitamin B1 ada di dalam susu formula. Tambahan susu formula dalam pola konsumsi anak sangat dianjurkan untuk melengkapi kebutuhan zat gizi dan nutrisi anak bagi pertumbuhan dan perkembangan. Namun terkadang pemberian susu formula ini malahan menimbulkan masalah bagi kesehatan anak, salah satunya berkaitan dengan kesehatan gigi dan mulut anak. Pola konsumsi susu Formula yang kurang tepat seperti cara penyajian yang menggunakan botol yang dihubungkan dengan lama pemberian, frekuensi, dan waktu pemberian dapat menyebabkan terjadinya karies pada anak (Sulistyoningsih, 2011)

Karies membawa dampak buruk dan dapat mempengaruhi kualitas hidup bagi anak. karies akan menimbulkan rasa nyeri dan ketidaknyamanan. Hal ini akan mengganggu aktivitas anak (Mukhbitin, 2015).

Berdasarkan uraian tersebut peneliti tertarik untuk mengetahui gambaran pengetahuan ibu tentang kebiasaan minum susu formula melalui botol dan terjadinya karies pada anak usia prasekolah di PAUD Nurul Iman Radio Dalam.

\section{Metode}

Jenis penelitian ini adalah penelitian deskriptif. Penelitian ini di lakukan di PAUD Nurul Iman Radio Dalam pada Januari sampai dengan April 2020. Populasi pada penelitian seluruh anak usia Prasekolah di PAUD Nurul Iman Radio Dalam Jakarta Selatan yang berjumlah 60 orang (anak dan ibunya). dilakukan pengambilan sampel dengan total sampling sehingga besar sampel penelitian ini sebanyak 60 orang juga atau 30 pasang anak beserta ibunya. Keadaan pandemic covid 19 yang sedang melanda membuat peneliti menyesuaikan metode pengumpulan data penelitian secara tepat, pengumpulan data pengetahuan ibu
(C) Jurusan Keperawatan Gigi Poltekkes Kemenkes Jakarta I J1. Wijaya Kusuma No. 47-48 Cilandak Jakarta Selatan, Indonesia email: jdht@poltekkesjakarta1.ac.id

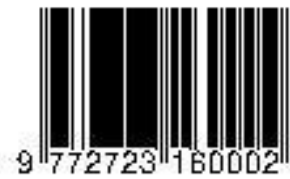


dilakukan dengan wawancara melalui media sosial whats app dan data status karies gigi anak merujuk hasil pemeriksaan skreening yang peneliti lakukan pada januari 2020. Data dianalisis secara deskriptif menggunakan distribusi frekwensi.

\section{Hasil Penelitian}

Hasil penelitian disajikan sebagai berikut:

Gambar 1. Distribusi usia awal anak mengkonsumsi susu botol

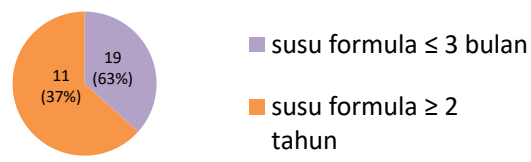

Berdasarkan gambar 1 menunjukkan dari 30 anak diketahui data terbanyak 19 (63\%) anak mulai mengkonsumsi susu botol pada usia $\geq 2$ tahun dan 11 (37\%) anak mulai mengkonsumsi pada usia $\leq 3$ bulan.

Tabel 1. Distribusi Pengetahuan Ibu tentang Kebiasaan Minum Susu Formula Melalui Botol

\begin{tabular}{llcc}
\hline No & $\begin{array}{c}\text { Kriteria } \\
\text { Pengetahuan }\end{array}$ & N & $\%$ \\
\hline 1 & Baik & 19 & 63,3 \\
\hline 2 & Cukup & 10 & 33,3 \\
\hline 3 & Kurang & 1 & 3,33 \\
\hline & Jumlah & 30 & 100 \\
\hline
\end{tabular}

Berdasarkan tabel 1 menunjukkan mayoritas pengetahuan ibu pada kategori baik yaitu 19 orang $(63,3 \%)$

Tabel 2. Distribusi Status Karies Gigi Susu (def-t) pada Anak Usia Prasekolah di PAUD Nurul Iman Radio Dalam

\begin{tabular}{clcc}
\hline No & Kriteria def-t & N & $\%$ \\
\hline 1 & Sangat Rendah (SR) & 6 & 20 \\
\hline 2 & Rendah (R) & 2 & 7 \\
\hline 3 & Moderat/Sedang (M) & 10 & 33 \\
\hline 4 & Tinggi (T) & 9 & 30 \\
\hline 5 & Sangat Tinggi (ST) & 3 & 10 \\
\hline & Jumlah & 30 & 100 \\
\hline
\end{tabular}

Berdasarkan tabel 2 diketahui mayoritas status karies gigi susu anak pada kriteria moderat yaitu 10 orang $(33 \%)$
Tabel 3. Distribusi pengatahuan ibu terhadap status Karies Gigi Susu (def-t) anak

\begin{tabular}{lcccccc}
\hline \multirow{2}{*}{$\begin{array}{c}\text { Pengetahuan } \\
\text { Ibu }\end{array}$} & \multicolumn{5}{c}{ Status karies gigi susu } & Jumlah \\
\cline { 2 - 6 } & SR & R & M & T & ST & \\
\hline Baik & 6 & 2 & 4 & 5 & 2 & 19 \\
\hline Sedang & 0 & 0 & 6 & 3 & 1 & 10 \\
\hline Buruk & 0 & 0 & 1 & 0 & 0 & 1 \\
\hline
\end{tabular}

Berdasarkan tabel 3 diketahui dari 19 ibu dengan pengetahuan baik paling banyak ditemui anak dengan status karies gigi susu kriteria sangat rendah yaitu 6 anak. kemudian dari 10 ibu dengan pengetahuan sedang paling banyak ditemui anak dengan status karies gigi susu kriteria moderat yaitu 6 anak, dan pada seorang ibu dengan pengetahuan buruk mempunyai anak dengan status karies gigi susu kriteria moderat.

\section{Pembahasan}

Hasil penelitian pada tabel 1 menunjukkan mayoritas pengetahuan ibu pada kategori baik yaitu 19 orang $(63,3 \%)$. Hasil penelitian ini konsisten dengan penelitian Rusmiati (2017) yang menunjukkan pengetahuan ibu tentang pemeliharaan kesehatan gigi dan mulut murid TK di Kecamatan Kota Baru Jambi tahun 2017 pada kriteria tinggi/baik sebesar 84,7\%.

Hasil penelitian ini memberikan gambaran bahwa informasi yang baik dalam menjaga kesehatan gigi anak dari kebiasaan minum susu formula melalui botol telah tersampaikan dengan baik pada orangtua anak. Perkembangan sumber informasi dimasa sekarang sangat mendukung untuk mendapatkan pengaetahuan kesehatan yang benar tersebut baik secara formal, melalui tenaga kesehatan maupun non forma. Menurut Notoadmodjo (2007) pengetahuan orangtua dapat dipengaruhi oleh banyak faktor, antara lain yaitu usia, pendidikan, status sosial ekonomi, pengalaman, informasi/media massa dan lingkungan Sedangkan menurut Zia (2018) Pengetahuan orang tua dapat diperoleh secara alami maupun secara terencana yaitu melalui proses pendidikan.

Hasil penelitian tabel 2 menunjukkan mayoritas status karies gigi susu anak pada kriteria moderat yaitu 10 orang $(33 \%)$. Hasil ini berbeda dengan penelitian Ayu, Dew, \& Wirata (2017) yang menunjukkan karies gigi sulung pada anak TK Sila Chandra III Batubulan tahun 2017 yaitu sebesar 4,9 atau pada kategori tinggi.
(C) Jurusan Keperawatan Gigi Poltekkes Kemenkes Jakarta I J1. Wijaya Kusuma No. 47-48 Cilandak Jakarta Selatan, Indonesia email: jdht@poltekkesjakarta1.ac.id

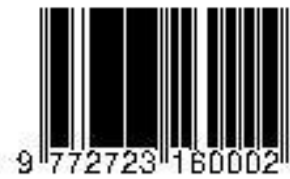


Perbedaan hasil kemungkinan berkaitan dengan karakteristik sampel yang berasal dari wilayah yang berbeda karena akan berkaitan dengan akses layanan kesehatan secara optimal, termaksud pola asuh orangtua dalam memelihara kesehatan gigi anaknya yang dapat saja berbeda. Keadaan moderat sesungguhnya belum menunjukkan status gigi geligi pada komunitas tersebut terpelihara dari karies, tetapi masih termaksud kelompok beresiko dengan kejadian karies pada gigi susu, telaah data yang mendalam pada tabel 2 menjukkan kelompok yang masuk kategori tinggi dan sangat tinggi (12 orang) lebih banyak daripada kategori sangat rendah dan rendah ( 8 orang), gambaran tersebut menunjukkan gigi susu sangat rentan mengalami karies gigi.

Menurut Andirajana (dalam Winda, Gunawan, \& Wicaksono, 2015) karies gigi dapat terjadi pada gigi susu dan gigi tetap, tetapi gigi susu lebih rentan terhadap karies karena struktur dan morfologi gigi sulung yang berbeda dari gigi tetap.

Hasil penelitian tabel 3 diketahui dari 19 ibu dengan pengetahuan baik paling banyak ditemui anak dengan status karies gigi susu kriteria sangat rendah yaitu 6 anak. Kemudian dari 10 ibu dengan pengetahuan sedang paling banyak ditemui anak dengan status karies gigi susu kriteria moderat yaitu 6 anak, dan pada seorang ibu dengan pengetahuan buruk mempunyai anak dengan status karies gigi susu kriteria moderat. Hasil tersebut memberikan gambaran secara deskriptif bahwa ada indikasi keterkaitan tingkat pengetahuan ibu dengan status karies gigi susu anak, meskipun untuk memastikkan hubungannya harus dibuktikan dengan analisis statistik lanjutan.

Hasil ini sejalan dengan hasil penelitian Yulianti \& Abi Muhlisin (2005) yang menunjukkan pada orangtua dengan pengetahuan yang kurang baik seluruhnya ditemukan keadaan anaknya dengan status karies.

Faktor yang mempengaruhi kejadian karies gigi anak adalah kebiasaan-kebiasaan ibu yang kurang baik terhadap pemeliharaan kesehatan gigi anak. Ibu sebenarnya memahami bahwa sebelum tidur anak seharusnya menyikat gigi, namun setiap kali diajak menyikat gigi anak marah atau ngambek, akhirnya ibu membiarkan anak tidur tanpa menyikat gigi terlebih dahulu. Kebiasaan ibu lainnya adalah kebiasaan jajan dan mengonsumsi makanan dan minuman manis, ketika ibu mengonsumsi makanan dan minuman tersebut otomatis anak juga ingin mengonsumsinya (Jayanti, 2012)

Status kesehatan gigi anak prasekolah sangat bergantung erat dengan pola asuh yang diterapkan oleh ib, menurut Purwaningsih, A.,dkk (2016) peran serta Ibu sangat diperlukan dalam membimbing, memberi pengertian, mengingatkan, dan menyediakan fasilitas kepada anak agar anak kelak dapat memelihara kebersihan gigi dan mulut.

\section{Kesimpulan dan Saran}

Kesimpulan

Berdasarkan hasil penelitian, dapat disimpulkan bahwa:

1. Pengetahuan ibu tentang kebiasaan minum susu formula melalui botol pada kategori baik

2. Status karies gigi susu anak anak usia prasekolah di PAUD Nurul Iman Radio Dalam pada kategori sedang.

Saran

Disarankan kepada ibu untuk lebih memperhatikan kesehatan gigi anak, berdasarkan pengetahuan yang ibu miliki dan mempraktikkannya secara langsung kepada anak untuk selalu menjaga kesehatan gigi dan mulutnya.

\section{Daftar Pustaka}

Ayu, G. A., Dew, C., \& Wirata, I. N. (2017). Gambaran karies gigi sulung dan tingkat pengetahuan orang tua terhadap pemeliharaan kesehatan gigi dan mulut pada anak pra sekolah di TK Sila chandra III batubulan tahun 2017. Jurnal Kesehatan Gigi, 6(1), 22-28.

Jayanti, C, D. (2012). Hubungan Tingkat Pengetahuan Ibu Tentang Karies Gigi dengan Kejadian Karies Karies Gigi Pada Anak TK Aisyiyah Kateguhanan Sawit Boyolali. Surakarta: UMS.

Jyoti, N. P. C. P. (2019). Hubungan tingkat pengetahuan dan perilaku ibu dalam merawat gigi anak terhadap kejadian karies anak di TK Titi Dharma Denpasar. 3(2), 96-102.

Kementerian Kesehatan RI. (2018). Hasil Utama Riset Kesehatan Dasar 2018. Jakarta : Kementerian Kesehatan RI

Mukhbitin, F. (2015). Gambaran kejadian karies gigi pada siswa kelas 3 MI Al-Mutmainnah. Jurnal
(C) Jurusan Keperawatan Gigi Poltekkes Kemenkes Jakarta I J1. Wijaya Kusuma No. 47-48 Cilandak Jakarta Selatan, Indonesia email: jdht@poltekkesjakarta1.ac.id

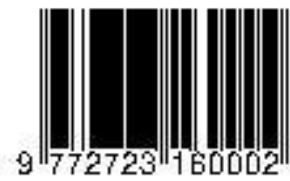


Promkes, 6(2), 155-166.

Notoadmodjo, S. (2007). Promosi Kesehatan dan Ilmu Perilaku. Jakarta: Rineka Cipta.

Purwaningsih, A., Sudaryanto, A. and Widodo, A. (2016). Pengaruh Pemberian Susu Formula Menggunakan Botol Susu (Dot) Terhadap Kejadian Rampan Karies Pada Anak Prasekolah Di Kelurahan Pabelan. Surakarta: UMS.

Rompis, C., Pangemanan, D., \& Gunawan, P. (2016). Hubungan tingkat pengetahuan ibu tentang kesehatan gigi anak dengan tingkat keparahan karies anak TK di Kota Tahuna. E-GIGI, 4(1). https://doi.org/10.35790/eg.4.1.2016.11483

Rusmiati, Rosmawati, R. D. S. (2017). Pengetahuan Ibu Tentang Pemeliharaan Kesehatan Gigi Dan Mulut Terhadap Karies Rampan Murid Taman KanakKanak ( Tk ) Di Kecamatan Kota Baru Jambi Tahun 2017. 2(2), 81-85.

Sandy, L. P. A., Kemenkes, R., \& Riskesdas, K. (2018). Permenkes 89 tahun 2015 tentang Upaya Kesehatan Gigi dan Mulut. Jurnal Teknosains, 44(8), 53.

https://doi.org/10.22146/teknosains.32343

Sulistyoningsih, H. (2011). Gizi untuk kesehatan ibu dan anak. Yogyakarta: Graha Ilmu.

Winda, S. U., Gunawan, P., \& Wicaksono, D. A. (2015). Gambaran Karies Rampan Pada Siswa Pendidikan Anak Usia Dini Di Desa Pineleng Ii Indah. E-GIGI, 3(1). https://doi.org/10.35790/eg.3.1.2015.6630

Yulianti, R. P., \& Abi Muhlisin. (2005). Hubungan antara Pengetahuan Orang Tua tentang Kesehatan Gigi dan Mulut dengan Kejadian Karies Gigi pada Anak di SDN V Jaten Karanganyar. Journal of Consumer Research, 32(1), 119-129. https://doi.org/10.1086/426622

Zia, H. K., Nurhamidah, N., \& Afriza, D. (2018). Hubungan Pengetahuan, Sikap Dan Perilaku Ibu Terhadap Kebiasaan Menyikat Gigi Anak. $B$ Dent, Jurnal Kedokteran Gigi Universitas Baiturrahmah, 1(1), 43-48. https://doi.org/10.33854/jbdjbd.51 